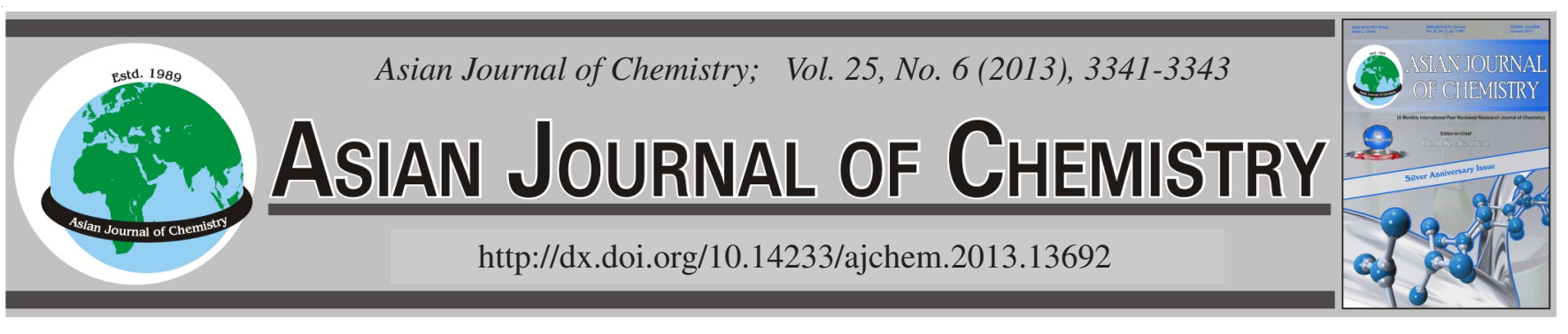

\title{
RP-HPLC Method for Simultaneous Estimation of Bromohexine Hydrochloride, Dextromethorphan Hydrobromide and Guaiphenesin in Soft Gel Capsules
}

\begin{abstract}
P.S. Mehta ${ }^{1, *}$ and V.B. PATEL ${ }^{2}$
${ }^{1}$ Department of Quality Assurance, Veerayatan Institute of Pharmacy, Post-Jhakhania, Tal. Mandvi, District Kachchh-370 460, India ${ }^{2}$ Department of Quality Assurance, Babaria Institute of Pharmacy, Varnama-391 240, India

*Corresponding author: E-mail: mpratik37@yahoo.com

(Received: 7 March 2012;

Accepted: 19 December 2012)

AJC-12582

A simple, precise and accurate reverse phase high performance liquid chromatographic method has been developed for simultaneous estimation of guaiphenesin, dextromethorphan hydrobromide and bromohexine hydrochloride in their soft gel formulations. The chromatographic conditions were standardized using Phenomenex Luna $\mathrm{C}_{18}(250 \mathrm{~mm} \times 4.6 \mathrm{~mm}$ i.d., $5 \mu \mathrm{m}$ particle size $)$ with UV detection at $258 \mathrm{~nm}$ and mobile phase consisting of methanol: $0.05 \mathrm{M}$ phosphate buffer $\mathrm{pH} 3.0(60: 40 \mathrm{v} / \mathrm{v})$. Mobile phase was delivered at the flow rate of $1.3 \mathrm{~mL} /$ min and separation was completed within $8 \mathrm{~min}$. The retention times of guaiphenesin, dextromethorphan hydrobromide and bromhexine hydrochloride were $3.1 \mathrm{~min}, 4.1 \mathrm{~min}$ and $6.8 \mathrm{~min}$ respectively. Calibration curves were linear with correlation coefficient 0.998 .0 .999 and 0.999 over a concentration range of $50-250,5-25$ and $1-6 \mu \mathrm{g} / \mathrm{mL}$ for guaiphenesin, dextromethorphan hydrobromide and bromhexine hydrochloride respectively. Recoveries were between 97.04-100.15, 101.92-104.67 and 102.01-102.55 respectively. The proposed method was validated and successfully applied to the estimation of three drugs in combined soft gel formulation.

Key Words: Guaiphenesin, Dextromethorphan hydrobromide, Bromohexine hydrochloride, RP-HPLC, Validation.
\end{abstract}

\section{INTRODUCTION}

Guaiphenesin, [3-(2-methoxyphenoxy)propane-1,2diol $]^{1-3}$ (GUA), acts as an irritant to gastric vagal receptors and recruit different parasympathetic reflexes that cause glandular exocytosis of a less viscous mucus mixture. Dextromethorphan hydrobromide (DEX), [3-Methoxy-17methylmorphinan hydrobromide monohydrate $]^{1-3}$, is an opioidlike drug that binds to and acts as antagonist to the NMDA glutamatergic receptor, it is an agonist to the opioid sigma 1 and sigma 2 receptors, it is also an $\alpha^{3} / \beta^{4}$ nicotinic receptor antagonist and targets the serotonin reuptake pump. Bromohexine hydrochloride (BROM) [N-(2-amino-3,5dibromobenzyl)- $N$-methylcyclohexanamine hydrochloride $]^{1-3}$, is a synthetic benzylamine derivative of alkaloid vasicine obtained from plant Athatoda vasaca. The drug reduces the viscosity of sputum by dissolving mucoploysaccharide fibres.

Guaiphenesin and DEX are official in IP, BP and USP and BROM is official in IP and BP. Pharmacopeias describes various methods for estimation of single drug like potentiometric method, iodometric method and HPLC method. Three UV (derivative and simultaneous) and various HPLC methods have been cited in the literature for estimation of guaiphenesin and DEX with other drugs in multicomponent formulations ${ }^{4-15}$.
However, no method is reported till date for simultaneous estimation of Guaiphenesin, DEX and BROM.

The present research work describes rapid, accurate and precise RP-HPLC method for simultaneous estimation of Guaiphenesin, DEX and BROM in their combined soft gel formulation.

\section{EXPERIMENTAL}

Guaiphenesin, DEX and BROM were kindly supplied as gift sample from Gujarat Liqui Pharmacaps Ltd. (GLPL), Vadodara, India. A commercial preparation (KOFEASE ${ }^{\circledR}$ ) used for analysis was procured form GLPL. Each soft gel capsule contains $100 \mathrm{mg}$ Guaiphenesin, $10 \mathrm{mg}$ DEX and $2 \mathrm{mg}$ BROM. HPLC grade methanol, HPLC grade water, potassium dihydrogen phosphate and glacial acetic acid of AR grade were procured from Merck, Mumbai, India.

HPLC was performed using a Shimadzu HPLC system consisting of a pump LC-20AD Plus, rheodyne sample injection port with 20 microlitre loop, UV detector SPD-20A plus, LC solutions software, column used was Phenomenex Luna $\mathrm{C}_{18}(4.6 \times 250 \mathrm{~mm}, 5 \mu)$. Weighing was done on Shimadzu Model BL-220 H balance and LI $610 \mathrm{pH}$ meter was used for adjusting $\mathrm{pH}$. 
Chromatographic conditions: A reverse phase column [Phenomenex Luna $\mathrm{C}_{18}(250 \mathrm{~mm} \times 4.6 \mathrm{~mm}$ i.d., $5 \mu \mathrm{m}$ particle size)], equilibriated with mobile phase [methanol: $0.05 \mathrm{M}$ phosphate Buffer $\mathrm{pH} 3.0$ adjusted with glacial acetic acid] was used. Mobile phase flow rate was maintained at $1.3 \mathrm{~mL} / \mathrm{min}$ and effluents were monitored at $258 \mathrm{~nm}$. The sample was injected using $20 \mu \mathrm{L}$ fixed loop rheodyne injector and run time was 10 mins.

Preparation of mobile phase and standard stock solution: Potassium dihydrogen phosphate was weighed (2.72 g) and dissolved in $400 \mathrm{~mL}$ of water. The $\mathrm{pH}$ was adjusted to 3.0 with glacial acetic acid. This solution was mixed with $600 \mathrm{~mL}$ of methanol. The solution was sonicated for $10 \mathrm{~min}$ and filtered using Whatman filter paper (No. 41) and used. The resulting solution was used as mobile phase. Guaiphenesin, DEX and BROM were weighed (10 mg each) in $10 \mathrm{~mL}$ volumetric flask separately and dissolved in mobile phase. The volume was made with mobile phase to get final concentration of $1 \mathrm{mg} / \mathrm{mL}$.

Calibration curve: Standard Stock solution of Guaiphenesin was further diluted to get solutions of concentrations 50, 100, 150,200 and $250 \mu \mathrm{g} / \mathrm{mL}$. Standard solution of DEX was further diluted to concentrations 5, 10, 15, 20, $25 \mu \mathrm{g} / \mathrm{mL}$. Standard solution of BROM was diluted as $1 \mathrm{~mL}$ to $10 \mathrm{~mL}$ with mobile phase. This solution was further diluted to get solutions of concentrations $1,2,3,4,5 \mu \mathrm{g} / \mathrm{mL}$. The solutions were injected using a $20 \mu \mathrm{L}$ fixed loop system and chromatograms were recorded. Calibration curves were constructed by plotting average peak area versus concentrations and regression equations were computed for GUA, DEX and BROM.

Determination of GUA, DEX and BROM in their combined dosage forms: Twenty capsules were emptied and oily paste was finely mixed. A quantity of oily paste equivalent to $100 \mathrm{mg}$ of Guaiphenesin, $10 \mathrm{mg}$ of DEX and $2 \mathrm{mg}$ of BROM was weighed and transferred to $100 \mathrm{~mL}$ volumetric flask. 80 $\mathrm{mL}$ mobile phase was added, sonicated for $35 \mathrm{~min}$ and the volume was made up to the mark with mobile phase. The solution was first filtered using Whatmann filter paper No. 41 and then through $0.45 \mu$ filter paper. Appropriate volume of the aliquot was tranfered to a $10 \mathrm{~mL}$ volumetric flask and the volume was made upto the mark with mobile phase to obtain $100 \mu \mathrm{g} / \mathrm{mL}$ of Guaiphenesin, $10 \mu \mathrm{g} / \mathrm{mL}$ of DEX, and $2 \mu \mathrm{g} / \mathrm{mL}$ of BROM. Such four replicates were made and injected in to the system at above chromatographic conditions and peak areas were measured. The quantification was carried out by keeping these values to the straight line equation of calibration curve. The method was validated for precision, accuracy, robustness, detection limit, quantitation limit and specificity.

Precision: The intra day and inter day precision study of Guaiphenesin (GUA), DEX and BROM was carried out by estimating the corresponding responses 3 times on the same day and on 3 different days for 3 different concentrations of GUA $(150,200,250 \mu \mathrm{g} / \mathrm{mL}), \operatorname{DEX}(15,20,25 \mu \mathrm{g} / \mathrm{mL})$ and $\operatorname{BROM}(3,4,5 \mu \mathrm{g} / \mathrm{mL})$ and the results are reported in terms of relative standard deviation.

Accuracy: The accuracy of the method was determined by calculating recoveries of GUA, DEX and BROM by method of standard additions. Known amount of Guaiphenesin (80, 100, $120 \mu \mathrm{g} / \mathrm{mL}), \operatorname{DEX}(8,10,12 \mu \mathrm{g} / \mathrm{mL})$ and BROM (1.6,
2.0, $2.4 \mu \mathrm{g} / \mathrm{mL}$ ) were added to a pre quantified sample solution and the amount of Guaiphenesin, DEX and BROM were estimated by measuring the peak areas and by fitting these values to the straight line equation of calibration curve.

Robustness studies: Robustness of the method was determined by small, deliberate changes in flow rate, mobile phase ratio and $\mathrm{pH}$ of mobile phase. Flow rate was changed to $1.3 \pm 0.05 \mathrm{~mL} / \mathrm{min}$. The mobile phase ratio was changed to 60 $\pm 1 \%$ for methanol, $\mathrm{pH}$ of mobile phase was changed to $3 \pm 0.1$

Detection limit and quantitation limit: A calibration curve was prepared using concentrations in the range of 5-25 $\mu \mathrm{g} / \mathrm{mL}$ for Guaiphenesin, $5-25 \mu \mathrm{g} / \mathrm{mL}$ for DEX and 1-5 $\mu \mathrm{g}$ / $\mathrm{mL}$ for BROM. The standard deviation of $\mathrm{y}$-intercepts of regression lines were determined and kept in following equation for the determination of detection limit and quantitation limit. Detection limit $=3.3 \mathrm{e} / \mathrm{s}$; quantitation limit $=10 \mathrm{e} / \mathrm{s}$; where $e$ is the standard deviation of the y-intercepts of regression lines and $\mathrm{s}$ is the slope of the calibration curve.

Specificity studies: Commonly used excipients (vegetable oil, soy lecithin, hydrogenated soya bean oil and yellow wax) were spiked into a pre weighed quantity of drugs. The chromatogram was taken by appropriate dilutions and the quantity of each drug was determined.

\section{RESULTS AND DISCUSSION}

The standard stock solutions of GUA, DEX and BROM were injected into the HPLC system and run in different solvent systems as mobile phases such as methanol, acetonitrile, buffers (phosphate, sodium acetate) in different proportions and finally methanol: $0.05 \mathrm{M}$ phosphate buffer adjusted to $\mathrm{pH}$ 3.0 with glacial acetic acid (60:40 v/v) was selected as an appropriate mobile phase, which gave good resolution and acceptable peak parameters for GUA, DEX and BROM.

As in marketed formulation, content of GUA is far greater (100 mg) than DEX (10 mg) and BROM (2 mg), a wavelength at which Guaiphenesin shows comparatively low absorbance than BROM was of concern. Overlain spectra of Guaiphenesin, DEX and BROM showed that at $258 \mathrm{~nm}$ all the three showed considerable absorbance and Guaiphenesin shows comparatively low absorbance than DEX and BROM and therefore it was selected as detection wavelength (Fig. 1)

The linear relationship was observed between the peak area and concentration over the range of $50-250 \mu \mathrm{g} / \mathrm{mL}$ for Guaiphenesin, 5-25 $\mu \mathrm{g} / \mathrm{mL}$ for DEX and $1-5 \mu \mathrm{g} / \mathrm{mL}$ for BROM. The linearity was expressed as correlation coefficient, which was 0.998, 0.999 and 0.999 for GUA, DEX and BROM respectively. Correlation coefficient, $y$ - intercept, slope of regression line are shown in Table-1. Precision was carried out as repeatability as per ICH guidelines. It was determined at 3 concentration levels with 3 replicates at each level. For all three concentration levels \% RSD obtained was less than $2 \%$ for all the three drugs. The results of precision are given in Table-2. The system suitability parameters for proposed method are shown in Table-3. The proposed method was evaluated in the assay of capsule formulation containing GUA, DEX and BROM. Four replicate determinations were carried out on capsules. \% assay found was $100.46 \%$ for GUA, for $100.03 \%$ DEX and that for BROM was $100.39 \%$. Results of 
capsule analysis was shown in Table-4. Robustness studies were carried out after deliberate alterations of flow rate, mobile phase compositions and mobile phase $\mathrm{pH}$. It was observed that the small changes in these operational parameters, did not lead to changes of retention times of peak of interest. Percentage of recovery shows that method is free from interference of the excipients used in the formulation (Table-5).

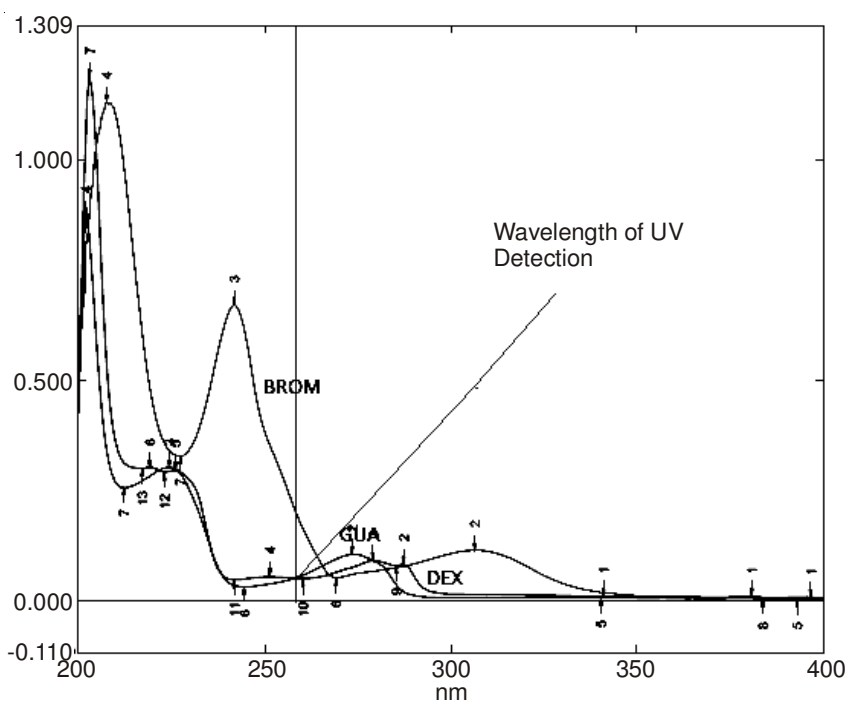

Fig. 1. Overlain spectra of all three drugs

\begin{tabular}{lccc}
\multicolumn{4}{c}{ TABLE-1 } \\
\multicolumn{4}{c}{ REGRESSION ANALYSIS OF CALIBRATION } \\
CURVE FOR THE PROPOSED METHOD \\
\hline Parameters & GUA & DEX & BROM \\
\hline Linearity range $(\mu \mathrm{g} / \mathrm{mL})$ & $50-250$ & $5-25$ & $1-5$ \\
Slope & 4892.8 & 1051.2 & 11997.4 \\
Intercept & 33792.2 & 257.74 & 4153 \\
Correlation coefficient & 0.9993 & 0.9996 & 0.9997 \\
\hline
\end{tabular}

The method described enables the quantification of Guaiphenesin, dextromethorphan hydrobromide and bromhexine hydrochloride in combined soft gel capsule dosage form. The validation data demonstrate good precision and accuracy, which prove the reliability of the proposed method. Hence, this HPLC method can be used routinely for quantitative estimation of all the three components in solid oral dosage form.

TABLE-2

SUMMARY OF VALIDATION PARAMETERS

\begin{tabular}{lccc}
\hline Parameters & GUA & DEX & BROM \\
\hline Limit of detection & 1.47 & 0.78 & 0.23 \\
Limit of quantitation & 4.45 & 2.39 & 0.72 \\
Precision $\left(\% \mathrm{RSD}^{\mathrm{a}}\right)$ & & & \\
Intra day $(\mathrm{n}=3)$ & 1.88 & 1.40 & 1.85 \\
Inter day $(\mathrm{n}=3)$ & 2.00 & 1.78 & 1.88 \\
\hline a $\mathrm{RSD}$ is relative standard deviation of three determinations &
\end{tabular}

TABLE-3

SYSTEM SUITABILITY PARAMETERS FOR GUA, DEX AND BROM BY THE PROPOSED METHOD

\begin{tabular}{lccc}
\hline System suitability parameters & GUA & DEX & BROM \\
\hline Retention time (min) & $3.1792 \pm$ & $4.1636 \pm$ & $6.8566 \pm$ \\
& 0.0067 & 0.0164 & 0.0127 \\
Resolution & 5.49 & 10.48 & - \\
Theoretical Plates & 6652.21 & 6119.83 & 8803.80 \\
Tailing factor (assymetric factor) & 1.24 & 1.43 & 1.15 \\
\hline
\end{tabular}

TABLE-4

ASSAY RESULT OF COMBINED DOSAGE FORM USING PROPOSED METHOD

\begin{tabular}{|c|c|c|c|}
\hline $\begin{array}{l}\text { Label claim } \\
\text { (mg/capsule) }\end{array}$ & $\begin{array}{c}\text { Concentration } \\
\text { estimated }\end{array}$ & $\begin{array}{l}\text { Concentration } \\
\text { estimated }(\%)\end{array}$ & $\begin{array}{c}\operatorname{RSD}^{\mathrm{a}}(\mathrm{n}=4) \\
(\%)\end{array}$ \\
\hline GUA (100) & 100.4681 & 100.4681 & 0.8604 \\
\hline DEX (10) & 10.0037 & 100.0371 & 2.0052 \\
\hline BROM (2) & 2.0079 & 100.3990 & 0.2822 \\
\hline
\end{tabular}

\begin{tabular}{ccccc}
\multicolumn{5}{c}{ TABLE-5 } \\
RECOVERY STUDIES \\
\hline $\begin{array}{c}\text { Label claim } \\
\text { (mg/capsule) }\end{array}$ & $\begin{array}{c}\text { Amount } \\
\text { added } \\
(\%)\end{array}$ & $\begin{array}{c}\text { Total } \\
\text { amount } \\
(\mathrm{mg})\end{array}$ & $\begin{array}{c}\text { Amount } \\
\text { found }(\mathrm{mg})\end{array}$ & $\begin{array}{c}\% \text { Recovery } \pm \\
\text { SD }^{\mathrm{a}}\end{array}$ \\
\hline GUA (100) & 80 & 180.00 & 180.28 & $100.15 \pm 1.19$ \\
& 100 & 200.00 & 198.20 & $98.70 \pm 1.29$ \\
& 120 & 220.00 & 213.49 & $97.04 \pm 0.42$ \\
\hline DEX (10) & 80 & 18.00 & 18.84 & $104.67 \pm 1.55$ \\
& 100 & 20.00 & 20.39 & $101.41 \pm 2.53$ \\
& 120 & 22.00 & 22.42 & $101.30 \pm 3.84$ \\
\hline BROM (2) & 80 & 3.60 & 3.69 & $102.55 \pm 0.29$ \\
& 100 & 4.00 & 4.08 & $102.01 \pm 0.33$ \\
& 120 & 4.40 & 4.49 & $102.14 \pm 0.10$ \\
\hline
\end{tabular}

${ }^{\mathrm{a}} \mathrm{SD}$ is Standard deviation of three determinations

\section{REFERENCES}

1. British Pharmacopoeia, London: The Stationery Office, vol. 1, 280, 632 and 976 (2009).

2. Indian Pharmacopoeia, Indian Pharmacopeoia Comission Ghaziabad, vol. 1 and 2, p. 195, 395 and 559 (2007).

3. United States Pharmacopoiea, USP32, NF27, The Official Compendia of Standards, Vol. 1, pp. 2106 and 2533 (2009).

4. A.R. Lee and T.M. Hu, J. Pharm. Biomed. Anal., 12, 747 (1994).

5. S. Gangwal and P. Trivedi, Indian J. Pharm. Sci., 60, 238 (1998).

6. M. Dhoka, V. Gawande and P. Joshi, Int. J. Pharm. Pharmaceut. Sci., 2, 129 (2010).

7. B. Jayalakshmi, J. Ramesh, T.N. Kalpana and R. Vijayamirtharaj, J. Pharm. Res., 3, 2868 (2010).

8. W.O. McSharry and I.V. Savage, J. Pharm. Sci., 69, 212 (1980).

9. S.M. Amer and M. Shehata, J. AOAC Int., 91, 276 (2002).

10. V.S. Lalit and B.B. Sanjaykumar, Pharm. Anal. Acta, 1, 1 (2010).

11. M.S. Bhatia, S.G. Kaskhedikar and S.C. Chaturvedi, Indian J. Pharm. Sci., 62, 61 (2000).

12. M.S. Bhatia, S.G. Kaskhedikar and S.C. Chaturvedi, Indian Drugs, 36, 702 (1999).

13. T. Mingchen and J.R. Pacifico, J. Chromatogr. Sci., 26, 636 (1988).

14. V.V. Vaidya, M. Khanolkar and J.N. Gadre, Indian Drugs, 38, 16 (2001).

15. V. Galli and C. Barbas, J. Chromatogr. A, 1048, 207 (2004). 